\title{
Is China's Investment A Debt Trap? -A Comparative Research Based on the Investment in the United States, Europe and China
}

\author{
Yichen Hao* \\ School of Political and Social Sciences, University of Glasgow, Glasgow, United Kingdom \\ *Corresponding author's Email: 2431178h@student.gla.ac.uk
}

\begin{abstract}
The essay is to prove that Chinese investments in developing countries are not a debt trap by comparing US, European and Chinese investments. This phenomenon has been observed in recent years and it was usually questioning China's motive of foreign investments from the perspectives of Western countries. The essay uses case study method. Through the case study of the US, European and Chinese foreign investments, the essay hopes to have broader lessons of knowing that there was no debt trap in Chinese foreign investments. The result of the essay reveals that the debt trap does not exist in Chinese investments in developing countries due to the lack of relevant evidence and Western countries' misunderstanding, even though US and European investments are different from China. In conclusion, the essay deepens our understanding of Chinese foreign investments, and to some extent, it will reveal that Western countries have stereotype towards Chinese investments in terms of the debt trap. Moreover, the essay can be useful to understand how to correctly view Chinese foreign investment approach, and explain that to a certain extent, Chinese investments have helped local economic development and objectively point out that there is still some room for upward mobility of Chinese investment approach in the region. Admittedly, the essay is limited in the way that in the international environment, state-to-state investments do not necessarily seek economic returns, but may also demand political returns. For example, US aid to Israel is fundamentally about preserving its political and economic interests in the Middle East. Further studies can look into the US, Europe and China's strategies towards developing countries and their roles in the investments.
\end{abstract}

Keywords: US, Europe, China, Investment, Developing Countries, Debt Trap.

\section{INTRODUCTION}

The essay's research question is whether Chinese foreign investments compose the debt trap through comparing with US and European investments in developing countries. This research question is puzzling because since 2000, Chinese foreign investment behavior has been controversial, especially among Western countries, led by European countries and the United States, and even refer to as debt trap diplomacy. The fact is that there are multiple reasons for the composition of a country's debt. This so-called debt trap that occurs by another country's investments is an extremely unbelievable thing.

To give background information, it is vital to discuss how to distinguish developed countries and developing countries. In terms of economic development level, the UN classifies all countries into two major categories: developed countries and developing countries. Under this broad frame, there are some other standards evaluating if it is a developed or developing country, such as fuel exporter and importer, and gross national income (GNI) [1]. According to the UN's developed and developing countries' lists, US and most European countries are defined as developed countries, but China is a developing country. Due to a quite low level of economic development, developing countries seek financial support from other developed countries, especially on foreign direct investments (FDI). FDI is a category of cross-border investment in which an investor establishes a lasting interest and a significant degree of influence over a firm residing in another economy, which is an essential element in international economic integration, that promotes economic development from technological transfer and 
international trade [2]. In this case, Gestrin demonstrates that FDI could provide more employment opportunities, accelerate technological developments, and stimulate developing countries to expand international markets [3]. These benefits have explained why developing countries consistently attracted FDI in recent years. According to Brautigam, the term "debt trap" first appeared in Northern India as a meme for China. And it also referred to Chinese debt-trap diplomacy. Then, this notion gradually spread throughout social media and most Western countries believed that China did have debt trap in foreign investments. The strangest thing was this phenomenon seemed to be specific to China. For instance, Washington doubted that China's global infrastructurebuilding strategy "the Belt and Road Initiative" (BRI) was not based on commerce. Instead, it was a weapon to expand China's global influences through emphasizing political ambitions that ruled the world [4]. However, this narrative revealed that Western countries thought that China's BRI might threaten their interests, so they used "debt-trap diplomacy" to defame the image of China in developing countries.

This essay will focus on US, European and Chinese investments in African and Latin American countries and interpret whether there is a debt trap through the example of Sri Lanka and BRI. It is a unique case because it is necessary to understand the differences among US, European and Chinese investments in developing countries, and then critically analyze the Chinese investments' debt trap. This case applies to the exploration of the differences between aid and investments in international investments.

This topic matters, because it shows a big picture of differences between Western countries and China's foreign investments and reflects the truth behind Western countries' discredit of Chinese debt trap. It can help understand Chinese foreign investments. Also, this research can be used as a reference to help Chinese investments make progress in developing countries. At the same time, it also further deepens the differences in behavior patterns between US and Europe and China in foreign investments.

The essay is divided into several sections. After the introduction, the essay will discuss both US and European investments in developing countries. Next, the essay will focus on Chinese foreign investments. The essay will then offer a comparison between US and European and Chinese investments. The essay will subsequently illustrate that Chinese investments are not a debt trap in detail. The final conclusion will make a summary for all sections, emphasize the significance of this research and lead to a discourse about potential limitations.

\section{US AND EUROPEAN INVESTMENTS IN DEVELOPING COUNTRIES}

\subsection{US Investments}

Before discussing US investments in developing countries, this essay will introduce USAID and its role in both foreign investments and American businesses. USAID was found by President Kennedy in 1961. Although USAID aimed to promote economic and social developments in those foreign countries through international aid, its creation represented US ambitions during the Cold War: By helping developing countries reduce poverty under the system of capitalism, US would gain more supports and weaken the power of communism. It is worth mentioning that USAID's roles changed over time, such as providing basic human needs (food, education, and health) in the 1970s, expanding markets and promoting economic growth in the 1980s, emphasizing sustainability in the 1990s, rebuilding infrastructures for war countries in the 2000s [5]. Monsen indicates that today USAID's objective is to help developing countries depend on themselves and follow own development steps for pursuing more resilient market economies in a global context [6]. In this process, investments play a significant role in stimulating American prosperity and opening more markets in developing countries. Overall, USAID had experienced numerous stages, but its focus was still foreign aid. This indirectly diminished the importance of FDI and maximize differences between aid and investments, even if US investments were also a part of USAID. OECD report presented the data that US was higher than average FDI between 1995 and 2000, which meant that the openness to FDI and trade was relatively not negative, whereas US investments were limited by comparing with other developed countries, such as France and UK [7].

Nevertheless, US FDI could not be ignored in developing countries since investments could bring more interests to US and improve economic conditions in developing countries. Therefore, there was an international agreement called bilateral investment treaties (BITs) that provided investors with legal protection and benefits in their investments. As a response, developing countries often agree with these treaties for more stable and long-term capital to increase own economies. Haftel gives an account of the relationship between BITs and FDI as an interplay. BITs indeed had positive effects on FDI, but only BITs in force could be effective to FDI inflows. In this case, American BITs took FDI seriously to ensure that no risks existed in investments. Because of historical reasons, US was unwilling to invest in developing economies without any compensations. Besides, developing countries still chose to conclude these agreements with US, while they tried to let US believe 
that they had made changes and would deserve FDI. On the other hand, if US investments failed to create economic returns in developing countries, then the circumstance would shift to developing countries' favorable treatments without any investment risks and loss of credits. On the contrary, developing countries would pay a heavy price if they betrayed BITs in force, because they offended investors and home country's government. At the same time, they would be notorious for their default in international community, which meant that investment decision could not estimate their losses [8]. So, developing countries were likely to be a scam of US BITs in force and FDI inflows, when US only cared about self-interests instead of helping developing countries to help themselves.

\subsection{European Investments}

From European perspectives, they attempted to change the status-quo of developing countries, especially on the aspects of investments. The project Europe Beyond Aid was created to formulate beneficial policies for both European countries and developing countries and improve European development policy in this process. One of the most essential measures in this project was the Commitment to Development Index (CDI), which used by evaluating European policies through development finance, investment, migration, trade, environment, security, and technology. Olivie and Perez states that since more and more international investments had helped developing countries to develop their economies, then CDI also began to examine investments in 2004. Besides this, official development assistance (ODA) also advanced FDI in developing countries by assessing economic relations between developed and developing countries, but foreign aid was gradually replaced by financial support. This led most European countries to pay more attention on FDI and increase FDI in developing countries, because this increase could contribute to the developing countries' economic demands. For instance, between the 1990s and 2010s, most developing regions' FDI inflows increased slightly and benefitted from this increase, such as East Asia and Pacific from 7.67 per cent to 8.85 per cent and Sub-Saharan Africa from 1.30 per cent to 1.49 per cent. In terms of investment type, FDI inflows increased dramatically in developing countries during the period 2000 through 2011, which were more than 69 per cent of total net FDI inflows [9]. These data shows that commitment to development was a key factor through European countries' investments in developing countries. FDI also boosted developing countries' economy. FDI was not only regarding developing countries' economic construction, but was also the consideration of European countries' growth and welfare. Through 'do not harm' measures, European countries could also benefit from FDI by promoting pro-development investment projects. Behind these projects, there was a login for CDI's promotion of FDI: While FDI stimulated in labour-intensive sectors, then would provide more employment opportunities for developing countries' people, and eventually caused a positive impact on European countries' development results [9]. Therefore, the interaction between CDI and FDI affected both developing countries and European countries in an optimistic way.

Although European countries' development policies on investments seemed stronger than other developed countries' investments, there were still some issues in their commitment to development. According to Europe's overall CDI performance in 2013, Europe's score (5.1) was just above the average by comparing with US (4.6) and Japan (3.3), but Europe was in the fourth ranking. Additionally, Europe's overall CDI score was far away from best score in the CDI during the decade from 2003 to 2013, even though Europe's financial component improved due to the balance of overall CDI score, which revealed that there was a still long way for Europe to go in promoting CDI performance and investing in developing countries. By contrast, European countries' CDI investment component was not negative. For example, UK (6.2), Norway (6.1) and Germany (6.0) were ranking subsequently as the second, third and fourth position. By observing their performances in CDI investment components of developing countries, it had explained why European countries could have higher scores. Europe's score in political risk insurance was 95 per cent, which was higher than prevention of bribery (79 per cent) and facilitating portfolio investment (88 per cent). A loophole existed in political risk insurance, which was without evaluating the consequences of investments, even though providing political risk insurance would be helpful to development-friendly investments in developing countries. However, the worst situation was against bribery and corruption, which constituted 38 per cent in investment subordination, since it violated the requirement in 'do not harm' index that promoted investments by preventing corruption in developing countries. In 2013, Europe's antibribery score was 23.6 and 79 per cent, which was behind Canada, Australia and US [9]. In summary, European CDI and investment performances were uneven processes, and this instability meant that European countries remained a lot of room for further improvements, especially in developing countries' investments.

\section{CHINESE INVESTMENTS IN DEVELOPING COUNTRIES}

As a developing country, China has made significant contributions to international investments in developing countries. At first, Ferchen gives insight into the essence of Chinese investments, that aid is not their main focus in development. Instead, to better engage with trade and investments, Chinese foreign policy and international development perspectives played a stronger role in reshaping international development and helping 
developing countries solve their issues. Chinese economic policy's narratives illustrate that China provided more chances for developing countries' economic developments through Chinese trade and investments, and China also benefitted from a more stable social order and geopolitical expansion by promoting own influences in developing countries' investments. At the same time, this win-win pattern in investments attracted developing countries and promoted diplomacy between China and other developing countries. However, many developing countries in Africa and Latin America suspected whether Chinese win-win pattern in their investments could satisfy their economic interests. For example, Brazil worried about investment relations with China, because it was limited by the framework of commodity dependency, which was that Brazil relied on exported raw materials rather than more profitable finished goods and better services. This also led Western countries to suspect Chinese aims behind these investments in developing countries were about selfinterests, which were the promotion of Chinese economic and geopolitical influences [10]. The main reason for this cognitive bias was the lack of communications regarding these differences based on international development. When China tried its best to adjust own economic policies by making positive changes and learning lessons from failures, nobody could understand China and developing countries were pushing back. In this case, it provided an indepth view for the problem of unilateral or multilateral investments in developing countries.

It is worth mentioning that most Chinese investments were about infrastructure in developing countries. According to Vieira, China's BRI fostered infrastructure sectors such as energy, transport and information and technology communication in developing countries as a part of investments, especially on energy investments. Between 2001 and 2014, China contributed to more than 360 billion dollars for energy supply, production, transport, and storage in developing countries. Behind this fund, there were two main components in energy investments: low-carbon and high-carbon energy investments. Overall, Low-carbon energy generation projects were almost twice as numerous as high-carbon generation projects, as it could be seen that the Chinese government supported transmission and hydro generation with large amount of funds. At the same time, many wind and solar projects has been steadily increasing since 2009 . It proved that China focused on low-carbon energy investments. On the contrary, China invested in high-carbon energy approximately 100 billion dollars, when low-carbon energy investments were only 60 billion dollars, even though China was still in the stage of breakthrough on low-carbon energy projects. This enormous gap resulted in the imbalance of low-carbon and high-carbon energy investments in developing countries. China invested oil and coal energy in some countries such as Brazil and Ecuador without any low-carbon energy projects. Back to Chinese infrastructure investments, China provided aid for developing countries, but it was similar to Ferchen's argument that Western countries could not understand what China was doing in international development. To solve this issue, Vieira suggests that China needed to show more information about their investments to other countries. Then, Western countries could try to cooperate with China to work hard together on foreign investments and learn with each other to recognize China's investments and future investments in developing countries [11].

Furthermore, through the case studies of Chinese investments in Africa and Latin America, the consequences of investments were different from each other. Based on these different circumstances, Western countries used them to criticize Chinese investments. African countries were willing to receive Chinese investments because of their early connections from the Ming Dynasty. China was swiftly shifting to a global power, but it persisted on investments in Africa. While Africa needed economic growth and infrastructure for development, China decided to distribute own resources and create more job opportunities. Mlambo states that there were various components of Chinese investments in Africa, such as infrastructure projects, loans, human resources, and access to Chinese market. Infrastructure and trade constituted a more substantial proportion in Chinese investments. In 2015, China's trade to Africa was 188 billion dollars in total, which was the highest foreign doner among other developed countries such as France and USA [12]. Africa also appreciated Chinese investments. According to their current relations, although it seemed that both China and Africa benefitted from the engagement, it was inevitable to have criticisms from Western countries and Africa. For example, African workers experienced unfair treatments such as low wages and insecure working conditions, and in the meantime, small African businesses were severely affected due to cheap Chinese imports [12]. Overall, Africa still needed Chinese short-term and long-term financial support, and more clear policies would consolidate China-Africa relations. Conversely, Latin America was opposite from Africa in Chinese investments. Both China and Latin America did not benefit from the investments because of modest economic growth and limited investments, even though China also invested in manufacturing and infrastructure [13]. So, Chinese investments in developing countries were different and uneven, but this gap derived from different situations in developing countries rather Chinese investments.

\section{MAKE A COMPARISON FOR US AND EUROPEAN AND CHINESE FOREIGN INVESTMENTS IN DEVELOPING COUNTRIES}




\subsection{Investment Objectives for Developing Countries and Host Countries}

When effective investments should bring benefits to both host countries and developing countries, it was essential to understand investment objectives and then learn about the logic behind investments. US and European countries were less interested in foreign investments than China, but they tended to desire for more benefits. Under this economic oppression, developing countries had to compromise US and European countries' investments, because these would be their stable funds to help them stimulate economic growth. However, Europe was better than US on investments' implement because of own identity as a major global power and consideration of self-interests. By contrast, Chinese investments could bring benefits to China and developing countries. China was willing to provide loans and jobs for them to change the statusquo. Instead, China would like to expand its influences through economy and geopolitics in this process. Although the West suspected Chinese investments' aims, China only wanted to reshape international development and influenced developing countries to bridge the gap in a global context. From Chinese perspectives, the reasons that developing countries needed financial support were likely to understand, which was improving their lives through economic growth. China had the same stance with these developing countries because China was also a developing country. It was a pity that Western countries could not have the same feelings with these developing countries, since they only focused on own benefits.

\subsection{Aid vs. Investments: Which One Is the Best Solution for Developing Countries?}

Although US, European Countries and China were positive to invest in developing countries, US regarded investments as foreign aid, European countries thought that investments were a part of foreign aid, and China devoted itself to take FDI as the backbone of developing economies. US had an international development agency called USAID, which was responsible for providing developing countries with assistance, such as food supply, healthcare, and investments. Its functions changed over time under different historic background. However, the main issue for USAID was based on aid rather foreign investments. According to American investments in developing countries, it could conclude that US was not quite interested in FDI due to investments' high risk and consideration of self-interests. To some extent, developing countries would not benefit from US investments, when US investments were slightly above average, and BITs limited developing countries' FDI inflows. The overall US foreign investments were not as enthusiastic as European countries and China.
European investments in developing countries were better than US. As one of the most influential global power, Europe aimed to help developing countries change their economic situations through FDI. Their project Europe Beyond Aid combined with CDI to examine European development policy in this process as well. Europe made significant contributions to developing countries' financial support, such as stimulating labour markets and creating more employment opportunities. It was a tragedy that high expectations of CDI did not show a positive result for European investments in developing countries, which was the same as US just above average level. Thus, European investments remained the stage of foreign aid and still needed to improve continuously for further investments in developing countries.

Chinese foreign investments were different from both US and European investments. China worked hard for international development, so promoted developing countries' economic growth through investments rather than stimulating foreign aid. Chinese investments distributed various areas, especially on infrastructure sectors. China improved own foreign economic policy and made breakthrough on FDI, even if Western countries made it difficult for China's non-transparent investments and criticized those Chinese investments ignored the recipient country's situations. Overall, Chinese investments were more effective than US and European countries, at least China honestly helped developing countries solve their problems and tried its best to support them. By contrast, US and European countries only wanted to show their influences more than their investments in developing countries. Chinese investments seemed to be the best option for developing countries, even though US, Europe and China had limitations on investments in developing countries.

\section{INTERPRET WHY THERE ISN'T A DEBT TRAP FOR CHINESE INVESTMENTS IN DEVELOPING COUNTRIES}

Through above comparisons, it could be seen that European investments were neutral, while European economic benefits might be affected, then intervened investments in developing countries. By contrast, the US investments seemed more radical, because US chased for own economic interests. Oppositely, under the comparison with the US and Europe, Chinese investments were conservative based on various benefits between China and recipient countries. Due to the specialty in Chinese investments, China had different perspectives on investments in developing countries. To have a better understanding towards the nature of Chinese investments, the case study of debt trap will be used to explore why Chinese investments 
were accused by Western countries and analyze why Chinese investments were not a debt trap.

Since China invested in developing countries and made accomplishments, the West accused China's investments as a debt trap, especially on BRI project. According to TRT World, China provided a number of loans for Africa and knew that they would not return debts back, then seized their assets in order to maintain its ambitious BRI, when BRI played a crucial role in global integration and Chinese economic interests. Similarly, Kenya had a tremendous external debt from China and increased from 1 billion dollars to 5.2 billion dollars between 2013 and 2017. If Kenya could not solve the issues of debts, then needed to give its seaport to China. Sri Lanka's Hambantota was handed to a Chinese operator, because Sri Lanka was unable to clear its debts [14]. Hence, Western countries thought that China took over indebted developing countries' infrastructure under a debt trap and this was regarded as a kind of neo-colonialism. However, Singh argues that it was not accurate to use a debt-trap diplomacy to describe Chinese finance. Through the case of Sri Lanka's Hambantota port, it was not used to return debts back to China. Singh clarifies that Sri Lanka's debt issue was not caused by China's loans, so it demonstrates that Chinese finance was not predatory based on assets, natural resources, and military expansion [15]. In general, there was no evidence regarding Chinese debt-trap diplomacy accusations, and this idea derived from US's worries about China's rising international role, which was not helpful to enhance welfare in developing countries. It was essential to recognize Chinese investments for diverse supports in developing countries.

From the point of view of Hameiri, China's debttrap diplomacy was a conspiracy that made up by Western countries to bring shame on China. Western countries used Sri Lanka as a typical example to bind with Chinese debt-trap diplomacy, but the main reason that Sri Lanka in debt was excessive loans from Western capital markets. Sri Lanka also could not govern Hambantota port and it was not about Chinese strategy. In addition, although some developing countries were indoctrinated by Western countries' notion of Chinese debt-trap diplomacy, the reality was that only China was willing to provide financial support for infrastructure [16]. Western countries' misunderstanding towards China was not related to China's strategic planning, but they were jealous owing to Chinese fast development and Chinese contributions to global progress. Likewise, Brautigam had a similar stance with Hameiri, that Chinese debt trap was a myth. Western sources claimed that China was using a coercive way to force developing countries to receive loans and construct infrastructure that these countries could not afford, then China could control these assets. Again, Brautigam discussed Sri Lanka's Hambantota port and explain why this threatened Western countries' benefits. This port was located in Southern Sri Lanka and around the Indian Ocean, which meant that 80 per cent trade would be covered here and this location made this port more strategic. If China would participate in its construction, then it would intensify Western competition. Eventually, China did not help build this port, but Sri Lanka borrowed 757 million dollars from China in 2012. Later China gave loans to Sri Lanka until 2017, Sri Lanka had to hand Hambantota port to China for not being able to return the debt on time. Then, Western countries started to depict Sri Lanka as a victim of China's debt trap, whereas it was not the truth and China was not the only one that benefitted from this. According to the contract, China would get access to Hambantota port, if Sri Lanka failed to return the debt, so it was not a debt trap [17].

Moreover, except Sri Lanka, Chinese investments in Angola and Venezuela could prove that there was no debt-trap diplomacy, which was against Western media's reports. Both cases undermined Chinese economic and geostrategic interests, since they needed more loans from China and used oil exchange loans, but eventually they failed to develop own infrastructure. Angola's slow development could not return the debt. Venezuela's long-term political and economic crises and cheap oil prices devastated own economy and could not repay the expensive debts. These examples interpreted why Chinese investments tended to become worse in Latin America instead of making changes. Especially when these countries could not pay back their loans, China was the one who had to bear all the losses, so it was impossible to say that China had a debt trap in investments. By exemplifying above countries' experiences, Brautigam insists that academia and media should be bold to challenge with hegemony without the fear of Western power, or no one was willing to tell the world truth [18]. Therefore, China did not have a debt trap and it was a rumor without any evidence, and Western countries were afraid of the rise of China, that would threaten their status.

\section{CONCLUSION}

In summary, the essay firstly has demonstrated some examples of both US and European investments in developing countries. Then has focused on the case study of Chinese foreign investments in Africa and Latin America. After that, it has discussed the differences among US, European and Chinese investments. Following that, it has been revealed that Chinese investments did not exist a debt trap. By doing so, the essay managed to answer the research question from the perspectives of US and European and Chinese foreign investments in developing countries.

The essay not only deepens our understanding of differences between US and European and Chinese 
investments, but also helps understand why Western countries have such prejudices towards China's debt trap. This research is vital to consider Chinese foreign investments by comparing with US and European investments. Then, it points out that Chinese investments still have a long road to improve under the questions of the "debt-trap diplomacy".

The essay has several limitations. The analysis may be not complete and there are other aspects. Economic aspects provide limited explanations and might not fully explain foreign investments. Political aspects could be another possibility to improve the analysis of investments.

Future studies can focus on other cases such as Western countries and China's strategies towards developing countries and their positions in foreign investments. Also, in order to fully understand the phenomenon, it may need to explore other reasons and perspectives.

\section{REFERENCES}

[1] UN. Country Classification. p.144. Retrieved from: https://www.un.org/en/development/desa/policy/wesp /wesp_current/2014wesp_country_classification.pdf

[2] Foreign Direct Investment (FDI). Retrieved from:

https://www.oecd-ilibrary.org/finance-andinvestment/foreign-direct-investment-fdi/indicatorgroup/english_9a523b18-en

[3] Gestrin, M. 2014. Putting Foreign Direct Investment to Work for Development. p. 71. Retrieved from: https://www.oecd-

ilibrary.org/development/development-cooperation-report-2014/putting-foreign-directinvestment-to-work-for-development_dcr-2014-9en;jsessionid=qJan2-V4-kxg5JYiKMwd-aDi.ip$10-240-5-41$

[4] Brautigam, D. 2019. "A Critical Look at Chinese 'Debt-Trap Diplomacy: The Rise of a Meme." Area Development and Policy, 5:1, 5.

[5] USAID. Retrieved from: https://www.usaid.gov/who-we-are/usaid-history

[6] Monsen, Lauren. 2020. U.S. Helps Developing Countries to Help Themselves. Retrieved from: https://share.america.gov/u-s-helps-developingcountries-to-help-themselves/

[7] OECD. 2002. Foreign Direct Investment for Development: Maximising Benefits and Minimising Costs. 11. Retrieved from: https://www.oecd.org/investment/investmentfordev elopment/1959815.pdf
[8] Haftel, Yoram. 2010. "Ratification Counts: US Investment Treaties and FDI Flows into Developing Countries." Review of International Political Economy, 17:2, 352-353.

[9] Olivie, I., and Aitor Perez. 2014. Europe Beyond Aid: The Role of European Countries in Fostering Development through International Investment. Center for Global Development. Retrieved from: https://www.cgdev.org/sites/default/files/EBAinvestment.pdf

[10] Ferchen, Matt. 2020. How China Is Reshaping International Development. Retrieved from: https://carnegieendowment.org/2020/01/08/howchina-is-reshaping-international-development-pub80703

[11] Vieira, Helena. 2018. China is investing in developing countries-what is it really up to? Retrieved from: https://blogs.lse.ac.uk/businessreview/2018/10/01/ china-is-investing-greatly-in-developing-countrieswhat-is-it-really-up-to/ LSE Online.

[12] Mlambo, D. 2018. The Rise of Chinese Investments in Africa: For Whose Benefit? Journal of Economics and Behavioral Studies, 10:4, 81-87.

[13] Ludena, Miguel. 2017. Chinese Investments in Latin America: Opportunities for Growth and Diversification. ECLAC-Production Development Series no. 208.

[14] TRT World. 2019. How China's Debt Trap Diplomacy Works and What It Means. Retrieved from: https://www.trtworld.com/africa/how-china-sdebt-trap-diplomacy-works-and-what-it-means-32133

[15] Singh, Ajit. 2019. The Myth of 'Debt-Trap Diplomacy' and Realities of Chinese Development Finance. Third World Quaterly, 42:2, 239-253.

[16]Hameiri, Shahar. 2020. Debunking the Myth of China's "Debt Trap Diplomacy". Retrieved from: https://www.lowyinstitute.org/theinterpreter/debunking-myth-china-s-debt-trapdiplomacy

[17] Brautigam, D., and Meg Rithmire. 2021. The Chinese 'Debt Trap' Is a Myth. Retrieved from: https://www.theatlantic.com/international/archive/ 2021/02/china-debt-trap-diplomacy/617953/

[18] Brautigam, Deborah. A Critical Look at Chinese 'Debt-Trap Diplomacy': The Rise of a Meme. Area Development and Policy, 5:1, 1-14. 